\title{
Primary angle-closure glaucoma in urbanized South African caucasoid and negroid communities
}

\author{
MAURIGE H. LUNTZ
}

Department of Ophthalmology, University of the Witwatersrand, and Johannesburg Teaching Hospitals, Johannesburg, South Africa

Primary angle-closure glaucoma (ACG) is said to be rare in Negroes (Rodger, 1958; Sarkies, I953; Neuman and Zauberman, I965; Av-Shalom, I966) when compared to white populations. Statistics for white patients attending glaucoma clinics give an incidence for ACG varying from 6 per cent. to 73 per cent. of all cases of primary glaucoma (Sugar, 1957; Smith, 1965). Studies from Africa south of the Sahara (excluding South Africa) and the United States of America suggest that angle-closure glaucoma is seldom if ever seen in Negroes, but Alper and Laubach (1968) have recently pointed out that the disease often passes unrecognised in American Negroes in whom it tends to occur in subacute or chronic form, while the acute form is rare.

Our largest communities are caucasoid and negroid. The urbanized negroid is almost at the level of sophistication of the caucasoid and both live under similar environmental conditions in close proximity to teaching hospitals (Beighton, 1971).

The caucasoid or white population stems from British, Dutch, French, and German ancestry.

South African Negroes are Bantu speakers and share a common gene pool with all Negroes south of the Sahara, with minor local variations (Tobias, 1971).

The same gene pool is therefore also shared by the American Negroes, although the latter have mixed to a considerable extent with the white population, a factor which may produce differences in the hereditary pattern of disease in these and South African Negroes. One thinks, for example, of the high incidence of pseudocapsular exfoliation syndrome in South African Negroes (Bartholomew, 197I; Luntz, 1972), a disease which is rare in American Negroes.

This paper describes the prevalence and clinical features of ACG in an urbanized South African White and Negro glaucomatous population and challenges the belief that acute and chronic ACG and the typical symptoms, pain, coloured haloes around lights, and blurring of vision, are rare in Negroes. The point is made that there are few differences in the prevalence and clinical features of ACG in these two ethnic groups. Such differences as do occur are readily explained when one bears in mind that Negroes come to hospital later than whites, so that when first seen the disease is more advanced and has caused more pathology (Luntz, 197I). 


\section{Material and definition of clinical terms}

A prospective study has been made of patients attending the glaucoma clinics of the Department of Ophthalmology of the University of the Witwatersrand. Special attention is given in this paper to ACG.

Great care has been taken to see all patients with primary glaucoma by referring them from the general clinics, casualty departments, and the wards to the glaucoma clinics. All patients admitted등 directly to the wards with ACG have been included. Patients with secondary glaucoma are excluded. Care was taken to exclude patients in whom ACG could be secondary to, for example, uveitis, $\underset{\mathcal{D}}{\circ}$ intumescent or hypermature lens, trauma, intraocular neoplasm, and prolonged miotic therapy.

\section{Definition of $A C G$}

A history of pain, redness of the eye of varying severity, headache, coloured haloes seen around naked light bulbs, blurring of vision, or loss of vision (occasionally after the use of a mydriatic) with응. raised intraocular pressure in the presence of visible angle closure and/or a pathological rise in intraocular pressure and angle closure precipitated by the dark room test. In chronic cases one may. find a closed angle with raised intraocular pressure in the absence of symptoms.

A further classification has been made into acute and subacute or chronic depending on the history and clinical findings. Thus, patients seen at the clinic during an attack of acute ACG or who give a clear history of one or more acute attacks (an acute onset of severe pain, redness, haloes, $\vec{C}$ severe visual impairment) are classified as cases of acute ACG. The remaining patients fall into two groups, subacute or chronic, and are classified as chronic. This form of classification has been $\vec{\oplus}$ used because acute ACG is said to be almost unknown in Negroes, a concept which is contrary to $\omega$ our experience.

\section{Results}

PREVALENGE

300 white patients were seen with raised intraocular pressure due to primary glaucoma or $\overrightarrow{\vec{O}}$ ocular hypertension from I 966 to September, I97 I, and I96 Negro patients were seen from September, I968, to September, I97 I. ACG was seen in sixty (20 per cent.) white patients and 35 ( 17 per cent.) Negro patients, an incidence of 0.002 per cent. in terms of the total white or Negro populations served by the clinic, i.e. the disease is equally prevalent in whites and Negroes (Table I).

Table I Prevalence of angle-closure glaucoma

\begin{tabular}{|c|c|c|c|c|}
\hline \multirow[b]{2}{*}{ Ethnic Group } & \multicolumn{2}{|l|}{ Number } & \multicolumn{2}{|l|}{ Percentage } \\
\hline & $\begin{array}{l}\text { All cases } \\
\text { primary glaucoma } \\
\text { (Glaucoma Clinic) }\end{array}$ & $\begin{array}{l}\text { Angle-closure } \\
\text { glaucoma }\end{array}$ & $\begin{array}{l}\text { Of all primary } \\
\text { glaucoma }\end{array}$ & $\begin{array}{l}\text { Of the population* served } \\
\text { (average annual figures) }\end{array}$ \\
\hline \multirow{2}{*}{$\begin{array}{l}\text { White } \\
\text { (1966-1971) } \\
\text { Negro } \\
\text { (1968-1971) }\end{array}$} & 300 & 60 & 20 & 0.002 \\
\hline & 196 & 35 & 17 & 0.002 \\
\hline \multicolumn{5}{|c|}{$\left.\begin{array}{l}\text { *White Population : 500,000 } \\
\text { *Negro Population : } 750,000\end{array}\right\}$ Government Census, 1960. } \\
\hline \multicolumn{5}{|c|}{$\begin{array}{l}\text { In Table II, the prevalence of the disease is expressed in terms of acute and chronic } \\
\text { ACG. These percentages are expressed graphically in Fig. I. In the white group, } \\
66.6 \text { per cent. of patients }(53.5 \text { per cent. of eyes }) \text { present with the acute disease and in the }\end{array}$} \\
\hline
\end{tabular}


Table II Acute and chronic angle-closure glaucoma

\begin{tabular}{|c|c|c|c|c|c|c|}
\hline \multirow{2}{*}{$\frac{\text { Race }}{\text { Glaucoma }}$} & \multicolumn{3}{|l|}{ White } & \multicolumn{3}{|l|}{ Negro } \\
\hline & Acute & Chronic & Total & Acute & Chronic & Total \\
\hline Patients & 40 & 20 & $6 o$ & I I & 24 & 35 \\
\hline $\begin{array}{l}\text { Eyes } \\
\text { Bilateral }\end{array}$ & $5^{2}$ & 45 & 97 & I 5 & $4^{I}$ & $5^{6}$ \\
\hline
\end{tabular}

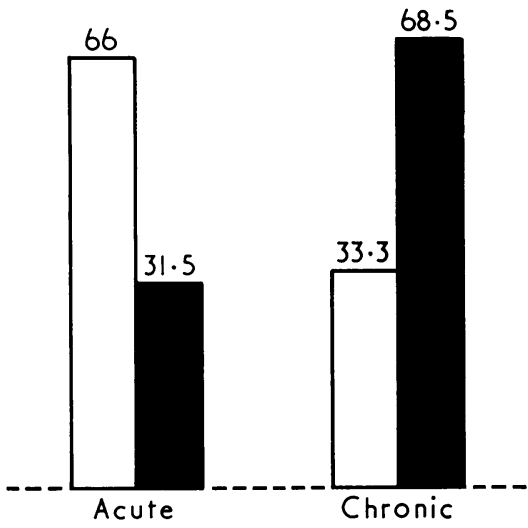

FIG. I Racial incidence (per cent.) of acute and chronic glaucoma

Negroes $3 \mathrm{I} \cdot 5$ per cent. (27 per cent. of eyes). The disease is bilateral in about two-thirds of the patients in both ethnic groups $(6 \mathrm{I} \cdot 5$ per cent. of white patients and 60 per cent. of Negroes).

\section{SEX DISTRIBUTION}

Table III reflects the ratio of males to females in each ethnic group for acute and chronic angle-closure types. In the White group there is a significant preponderance of females as indicated by a male to female ratio of $\mathrm{I}: 2.2$. There are twice as many females as in open-angle glaucoma from the same clinic, and a female preponderance when compared with the average annual eye clinic population and the population of Johannesburg.

Table III Sex distribution

\begin{tabular}{|c|c|c|c|c|c|c|}
\hline \multirow{2}{*}{$\frac{\text { Race }}{\text { Type }}$} & \multicolumn{3}{|l|}{ White } & \multicolumn{3}{|l|}{ Negro } \\
\hline & Male & Female & Ratio: $M / F$ & Male & Female & Ratio: $M / F$ \\
\hline Acute & 8 & $3^{\mathbf{I}}$ & I :4 & 7 & 4 & I :0.6 \\
\hline Chronic & I I & Io & I:I & 13 & I I & I :0.8 \\
\hline Total & 19 & $4^{I}$ & I :2.2 & 20 & 15 & I :0.75 \\
\hline $\mathrm{OAG}^{*}$ & 86 & IO4 & $1: 1.25$ & 100 & 40 & $\mathrm{I}: 0.4$ \\
\hline $\begin{array}{l}\text { Average } \\
\text { annual } \\
\text { eye clinics }\end{array}$ & 2,376 & 3,968 & $\mathbf{1}: \mathbf{1} \cdot 7$ & 16,400 & I I, 320 & I :0.6 \\
\hline \multicolumn{6}{|c|}{ Johannesburg population (6o-70 years) I 1.1 .5} & $1: 0.75$ \\
\hline
\end{tabular}

*OAG $=$ Patients with open-angle glaucoma in the glaucoma clinic. 
Similarly, there are more Negro females with ACG (male to female ratio I :0.75) when compared with open-angle glaucoma for the same clinic (male to female ratio I:0.4) and with the average annual eye clinic population ( $1: 0.6)$.

A comparison of the white and Negro populations for Johannesburg shows a preponderance of Negro males (male to female ratio $\mathrm{I}: 0.75$ ). This distortion of the sex distribution in the Negro population is caused by a selective migration of Negro males from rural areas to the city in search of employment and is reflected in the eye clinic and glaucoma clinic populations.

A GE

The average age and range of ages is recorded in Table IV, separately for males and females. In whites the average age is $5^{8}$ years, in Negroes a little younger at 55.5 years. This is accounted for by the younger average age of Negro females. The Negro population of Johannesburg is younger than the white population (Luntz, I97I) and the Glaucoma Clinic population reflects this difference. The age distribution in decades is illustrated graphically in Fig. 2, showing a more uniform distribution in Negroes.

Table IV Age

\begin{tabular}{|c|c|c|c|c|c|c|}
\hline \multirow{3}{*}{$\begin{array}{l}\text { Race } \\
\text { Sex }\end{array}$} & \multicolumn{3}{|l|}{ White } & \multicolumn{3}{|l|}{ Negro } \\
\hline & \multirow{2}{*}{ No. patients } & \multicolumn{2}{|c|}{ Age (yrs) } & \multirow{2}{*}{ No. patients } & \multicolumn{2}{|c|}{ Age (yrs) } \\
\hline & & Mean & Range & & Mean & Range \\
\hline Male & I9 & $5^{8}$ & $34-75$ & 20 & $5^{8}$ & $20-75$ \\
\hline Female & $4 \mathrm{I}$ & $5^{8.5}$ & $35^{-76}$ & 15 & 53 & $3^{2-79}$ \\
\hline Total & $6 o$ & $5^{8}$ & $34^{-76}$ & 35 & $55 \cdot 5$ & $20-79$ \\
\hline
\end{tabular}

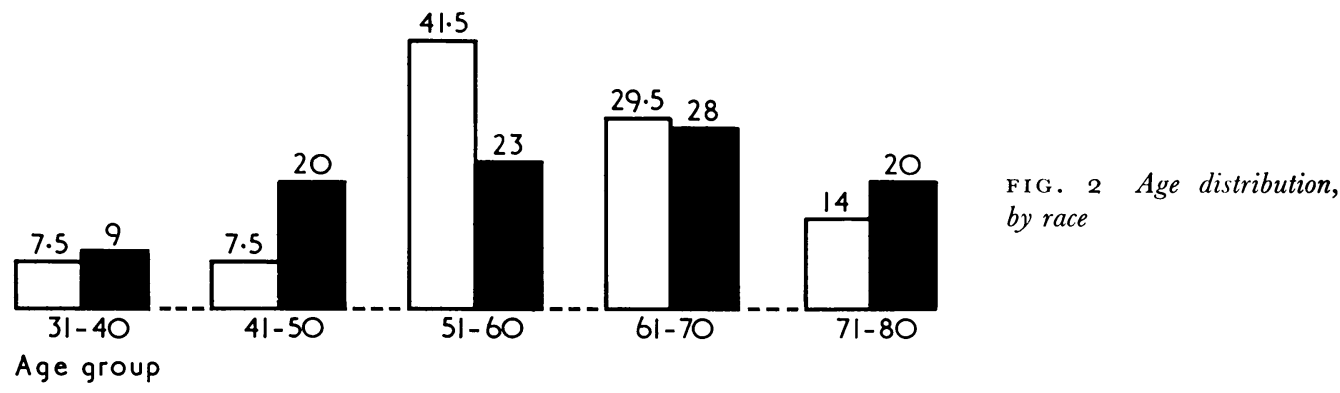

SYMPTOMS

Figs 3 and 4 summarize the symptoms of AGG as elicited by history taking. The most striking difference is that many more white eyes ( 17 per cent.) than Negro ( 7 per cent.) are classified as "acute angle-closure glaucoma" on a history of one or more acute attacks without the ophthalmologist seeing the patient in an acute attack. This reflects the strictness of the criteria. Only one Negro gave a history of acute ACG that was sufficiently accurate to be accepted. The remainder were rejected and classified as chronic ACG. This difference between white and Negro patients is partly accounted for by differences in education, the ability to remember and convey symptoms accurately, and difficulties 

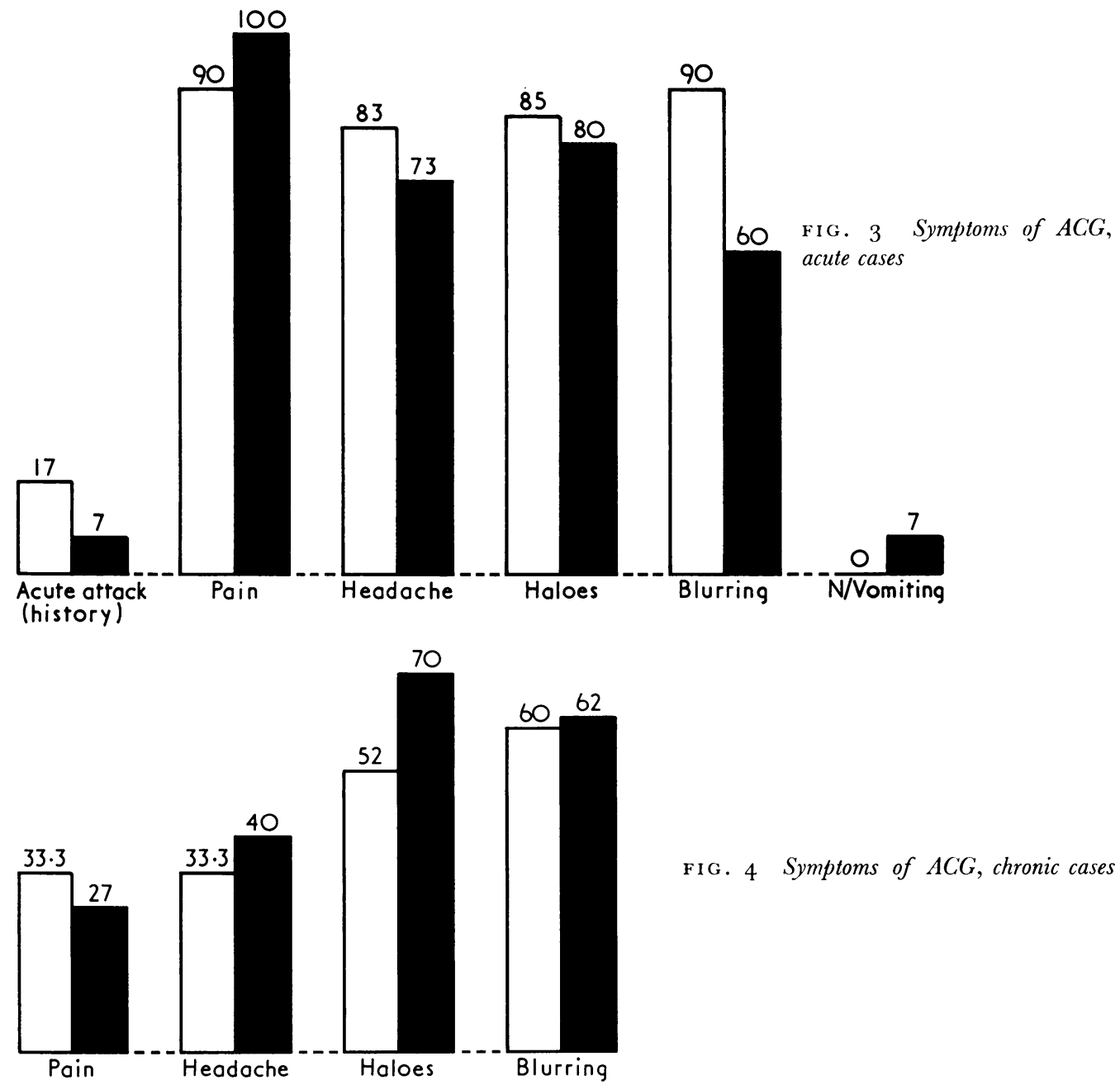

with language, so that there are probably some Negroes with acute ACG who, because they gave a poor history, have been classified as chronic ACG. Therefore these statistics reflect the minimum incidence of acute ACG in Negroes.

The only other difference of note is that Negroes with chronic ACG complained of seeing haloes (70 per cent.) more often than whites ( $5^{2}$ per cent.) (Fig. 4), another indication that some Negroes with acute ACG have been classified as having chronic ACG

Apart from these two points of difference there is remarkable similarity in the clinical histories given by white and Negro patients.

DURATION OF SYMPTOMS

Negroes present to hospital much later than white patients and this is clearly demonstrated for chronic ACG. The average duration of symptoms before seeking medical advice is I $\cdot 9$ years in Negroes and $0 \cdot 8$ years for whites.

The findings on physical examination are graphically compared in Fig. 5 (all cases of AGG), Fig. 6 (acute AGG), and Fig. 7 (chronic AGG). 

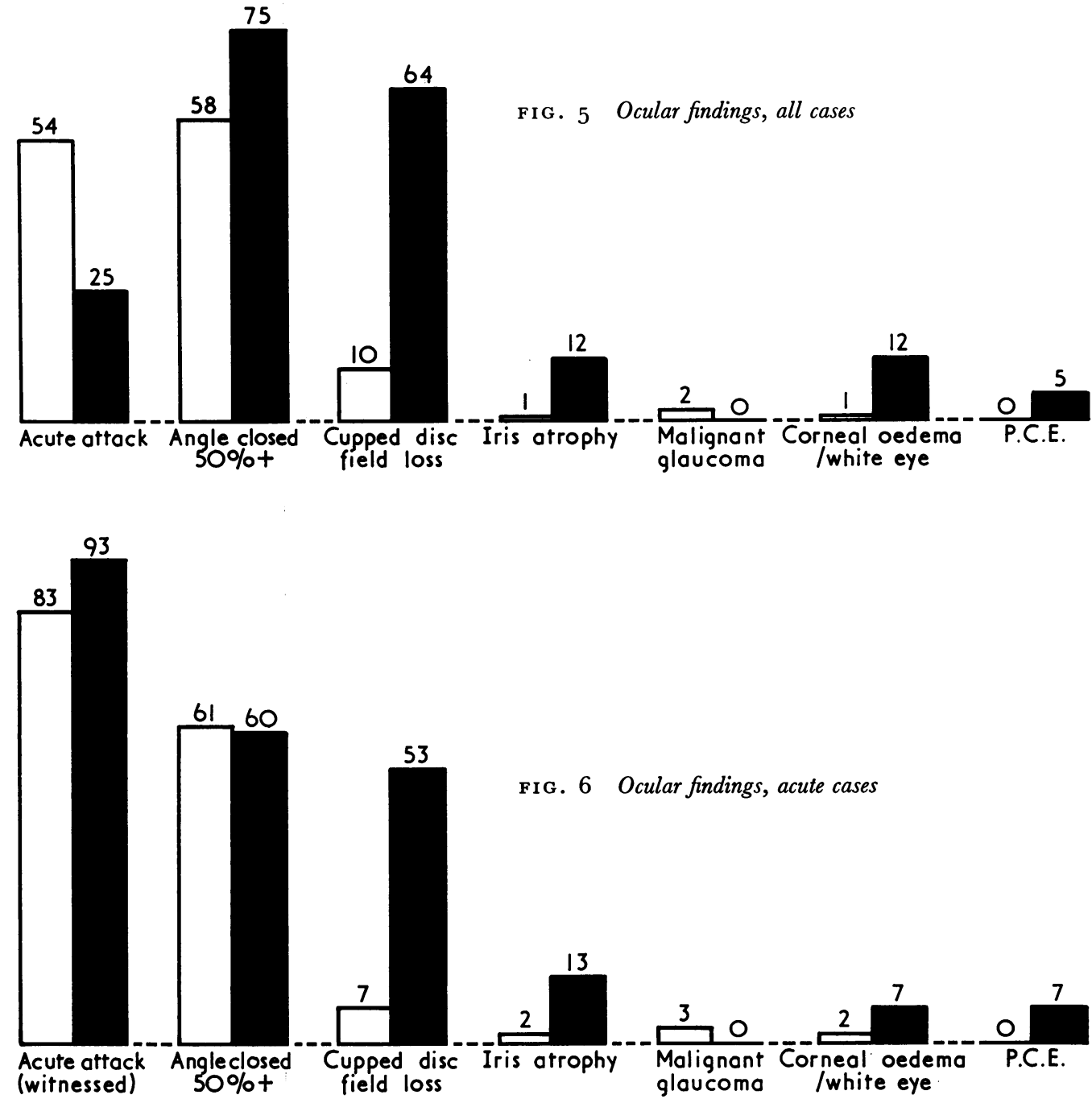

\section{Results of ocular examination}

ACUTE ATtack

Acute ACG is considerably more frequent in white patients ( 53 per cent. of all eyes with AGG) than in Negro patients (25 per cent. of all eyes with ACG) but is nevertheless not $\widetilde{O}$ infrequent in Negroes. Over 80 per cent. of white and Negro patients with acute AGG presented to hospital during an acute attack (Fig. 6).

GONIOSCOPY

Gonioscopically 60 per cent. of the eyes of white and Negro patients with acute AGG close off more than 50 per cent. of the circumference of the angle (Fig. 6), but in the chronic $\frac{D}{\mathbb{D}}$ disease about twice as many Negro (89 per cent.) as white eyes (53 per cent.) develop this $\frac{\Omega}{\mathbb{D}}$ degree of angle closure. 


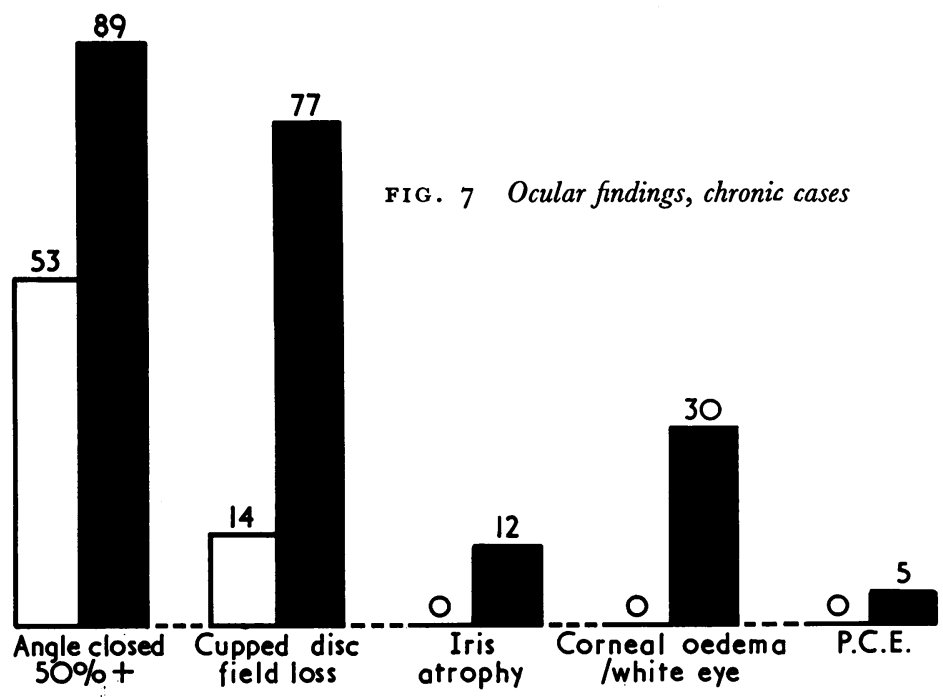

GLAUCOMATOUS GUPPING OF THE OPTIC DISG

This is a prominent feature in eyes of Negro patients with acute and chronic disease (64 per cent.) but is unusual in eyes of white patients (Io per cent.) (Figs 5, 6, and 7).

IRIS ATROPHY, "WHITE EYE", PSEUDOGAPSULAR EXFOLIATION OF LENS CAPSULE

Three other physical signs occur prominently in eyes of Negro patients, i.e. iris atrophy, corneal oedema in the presence of a high intraocular pressure and a white, quiet looking eye, and pseudocapsular exfoliation syndrome (Fig. 5).

A dark-room test was done only in cases in which the gonioscopy or history left some doubt as to the diagnosis. In these patients a positive dark-room test was accepted as confirmatory evidence of ACG.

\section{MALIGNANT GLAUGOMA}

This occurred in two eyes of two white patients operated on for acute AGG (Fig. 6).

\section{Symptoms and clinical features}

We have seen in Negroes all the classical ways in which angle closure presents. Some illustrative case reports are mentioned.

\section{CASE REPORTS}

Acute angle-closure glaucoma

(x) Negro female seen at the age of 42 years. This patient had a typical acute ACG in the right eye of some weeks' duration, which followed the death of one of her children. She gave a 2-week history of severe pain and redness in the eye and headache. She complained of seeing coloured rings around lights and before the acute attack intermittent attacks of blurring of vision. There was ocular redness and congestion, corneal oedema, shallow anterior chamber, and patches of iris atrophy. Intraocular pressure was measured as $54 \mathrm{~mm} . \mathrm{Hg}$ in the right eye and $30 \mathrm{~mm} . \mathrm{Hg}$ in the left. The attack was checked by medical therapy and a few days later a peripheral iridectomy was done. Postoperatively the anterior chamber deepened and the angle opened as far as the scleral 
spur over about one-third of its circumference. The intraocular pressure remained out of control and a posterior lip sclerectomy was done which then controlled the pressure. However, the disc was cupped and atrophic, and vision remained at hand movements.

A few weeks later the patient developed a typical acute attack in the left eye while on miotic therapy; this attack was treated in the same way, but within a few hours of the onset of the attack. Postoperatively the angle opened and vision has returned to 20/20. This patient has had no further trouble.

\section{Mixed glaucoma}

(2) Negro male aged 47 years. This man came to the hospital with bilateral acute ACG of 2 months' duration. This was treated by intensive medical therapy, followed by peripheral iridectomies. Both optic discs were noted to be cupped. Postoperatively the left eye remained congested and blind. In the right eye the condition settled and the angle opened, but the intraocular pressure remained raised in the absence of congestion. The patient now has chronic open-angle glaucoma which is controlled by medical therapy.

\section{Chronic "quiet" angle-closure glaucoma}

(3) Negro female aged 52 years. This patient's history is typical of chronic ACG in Negroes. She came to hospital complaining of diminished visual acuity in the right eye for one year and in the left for 6 months. She had no other symptoms. The visual acuity was reduced to perception of light in both eyes. There was bilateral corneal oedema but the eyes were white and quiet. The anterior chambers were shallow. Both optic discs were grossly cupped and atrophic. Gonioscopy showed that both angles were apparently closed over Ioo per cent. of their circumference. The intraocular pressure was over $60 \mathrm{~mm}$. $\mathrm{Hg}$ in both eyes. The visual acuity did not improve when the intraocular pressure was controlled by filtration surgery.

\section{Subacute angle-closure glaucoma}

(4) Negro female aged 50 years. This patient presented with subacute ACG in 197I. For about a year she had noted with the right eye coloured haloes around lights at night, epiphora, and blurring of vision. A few weeks later the same symptoms started in the left eye. These attacks were intermittent. The visual acuity was $20 / 20$ in both eyes and the optic discs and visual fields were normal. Intraocular pressure was $26 \mathrm{~mm}$. $\mathrm{Hg}$ in the right eye and $16 \mathrm{~mm}$. $\mathrm{Hg}$ in the left. The anterior chambers were shallow (right $2 \mathrm{~mm}$. deep, left $2 \cdot 1 \mathrm{~mm}$. deep) measured with the HaagStreit attachment and slit lamp. Both angles were very narrow, only Schwalbe's line being visible, and they appeared to be closed in about 25 per cent. of the circumference. The eyes settled well after peripheral iridectomy.

\section{Discussion}

\section{(1) Prevalence}

Primary adult glaucoma is aetiologically classified into open-angle and angle-closure (Barkan, 1938). Heredity plays a part in the aetiology of these diseases and therefore racial differences, climate, and culture may influence the disease pattern. The two ethnic groups selected for this study are urbanized and live in similar environmental conditions although the white group is rather more sophisticated than the Negro (Beighton, I97I). There are also cultural differences, but these are least obvious in urbanized communities. The major factor that could modify disease between these ethnic groups is therefore racial, while environmental and cultural influences are minimal. This factor has had little impact on AGG because the prevalence and clinical features are similar in the white and Negro groups with the major difference that acute ACG is less frequent in Negroes than in whites, 
although as has already been noted this latter difference is magnified by differences in education and language which distort history-taking.

On the other hand, various authors have studied primary AGG in Negroes outside South Africa and all agree that the disease, although common in whites (6 to 73 per cent. of all adult patients with primary glaucoma) is rarely totally absent in Negroes.

Thus Rodgers (1958), working in Ghana, North Nigeria, and the Cameroons, stated that "It (primary glaucoma) was never seen in a congestive stage, only rarely did we find bedewing. The angles as viewed by a Goldmann gonioscope were wide and open."

Sarkies (1953), working in Accra, Ghana, analysed 2,312 hospital outpatients. He stated "I have yet to see an African with primary glaucoma in a congestive phase....". However gonioscopic examination was not done and 6 per cent. of his patients gave a history of "haloes" around lights and 4 per cent. complained of transient blurring of vision especially in the early mornings. It is possible that some of these patients were suffering from ACG.

Alper and Laubach (1968) studied the disease in American Negroes and found that classical acute AGG with congestive signs and symptoms was rare but that "subacute and chronic angle-closure glaucoma does occur in the Negro with some regularity; however it is usually misdiagnosed and treated as chronic simple glaucoma". It is significant that many of their cases of chronic ACG had been diagnosed and treated in the glaucoma clinic for many years as cases of open-angle glaucoma before they were re-examined and found to be cases of angle closure. It is possible, however, that some patients in their retrospective study were cases of primary open-angle glaucoma who had developed secondary subacute or chronic angle closure from long-term miotic therapy, a complication of long-term therapy that we have noted in our own patients. Nevertheless, in their prospective study, they saw fourteen Negroes with primary ACG.

The background to our present knowledge of ACG in Negroes is important in the context of the results published here. Our experience with the South African Negro is so different. The prevalence of primary ACG in relation to all primary glaucoma patients seen in our glaucoma clinic and in relation to the total population drained by the teaching hospitals is equal or near equal in white and Negro patients, a prevalence as high as 8 to 20 per cent. of all primary glaucoma patients. As all Negroes in sub-Sahara Africa and in the U.S.A. share the same gene pool, this striking difference is unlikely to be due to genetic factors.

The high number of patients with absolute glaucoma presenting to clinics in African countries to the north of South Africa makes accurate assessment of the prevalence of the types of glaucoma difficult and some cases of ACG could be overlooked. In our glaucoma clinic population only three white and four Negro patients came to hospital with disease which was too advanced for an accurate diagnosis to be made.

\section{(2) Predisposing factors}

The chief predisposing factor seems to be the depth of the anterior chamber, the shallower the chamber the higher the risk of AGG. Lowe calculated a "threshold" for risk for ACG as an anterior chamber depth of $2.5 \mathrm{~mm}$. and stated that primary ACG was rare with anterior chambers deeper than $2.5 \mathrm{~mm}$. (Lowe, 1972). It is therefore pertinent that in a study from this clinic of 25 Negro eyes and 25 white eyes with primary glaucoma there was no statistical difference in anterior chamber depths in the two ethnic groups; a mean depth for Negro eyes of $2.59 \mathrm{~mm}$. (a minimum of $2 \mathrm{~mm}$.) and for white eyes of $2.39 \mathrm{~mm}$. (a minimum of $2 \mathrm{~mm}$.) (Luntz, 1970).

In a similar study of fifty normal Negro and fifty normal white eyes in the age group 
40-6o years, there was no statistical difference in anterior chamber depth measurements of white and Negro females, but the anterior chambers of Negro males were on average deeper than those of white males to a statistically significant degree. Nevertheless, in all groups, the minimum chamber depth was less than $2 \mathrm{~mm}$. (Luntz, 1970).

(3) Symptoms

Only one Negro patient gave a history of acute attacks of ACG which was absolutely typical and could be accepted as diagnostic; in the white group there were nine but the percentage of white and Negro patients complaining of pain, headaches, and coloured haloes around lights were almost identical (Fig. 3).

Blurring of vision was rather more prominent in white patients, probably because it is easier for white patients, who are on the whole better educated, to comprehend what is meant by blurring.

These findings are strikingly different to reports taken from Negro populations elsewhere including the U.S.A. It is difficult to account for such a marked difference, except to remark that in our clinic a great deal of time was spent obtaining a full and adequate history.

\section{Clinical features}

Negro patients endure their symptoms longer than whites before seeking medical advice (Fig. 5) and thus have a higher incidence of glaucomatous cupping of the disc and iris atrophy. Permanent angle closure is more frequent and extensive (Fig. 5). This influences the surgical management and makes treatment more difficult and complex.

A peculiar feature of acute and chronic AGG in Negroes, which was seen in thirteen eyes and has also been noted by Alper and Laubach (1968), is documented in Fig. 5, i.e. eyes manifesting raised intraocular pressure, corneal oedema, and iris oedema but remain "white" and quiet-looking throughout. This was seen only in one white patient.

Pseudocapsular exfoliation syndrome is seen in 5 per cent. of Negro eyes but is absent in whites. It is seen in about 20 per cent. of the Negro population (Luntz, 1972) and is uncommon in ACG when compared to the population in general.

\section{Management of ACG in Negro patients}

\section{TREATMENT}

Our approach to the treatment of AGG is surgical, i.e. peripheral iridectomy in all cases except those in which the intraocular pressure before operation remains over $30 \mathrm{~mm} . \mathrm{Hg}$ on very intense medication for 48 hours including hyperosmotic agents, in whom we do filtration surgery (Scheie operation).

RESULTS (Tables V and VI).

The results are expressed as "cured", "controlled", or failed". By "cured" is meant normalization or near normalization of the intraocular pressure and no progression of the disease as measured by visual field examination at regular intervals, usually 3-monthly.

If topical medication is required postoperatively to control the disease, the result is indicated as "controlled".

Fifteen eyes presented with acute ACG. One with absolute glaucoma without pain did not require treatment. One is controlled medically. Thirteen had peripheral iridectomies, and ten ( 77 per cent.) are controlled (seven do not require postoperative 
Table $\mathbf{V}$ Results of peripheral iridectomy in 13 of 15 eyes with acute angle-closure glaucoma

\begin{tabular}{|c|c|c|}
\hline \multirow{2}{*}{ Result } & \multicolumn{2}{|l|}{ Eyes } \\
\hline & No. & Per cent. \\
\hline $\begin{array}{l}\text { Cured } \\
\text { Controlled } \\
\text { Failed }\end{array}$ & $\begin{array}{l}7 \\
3 \\
3\end{array}$ & $\begin{array}{l}54 \\
23 \\
23\end{array}$ \\
\hline Total & $13^{*}$ & 100 \\
\hline
\end{tabular}

*Also I eye treated medically I eye with absolute glaucoma
Table VI Results of peripheral iridectomy in subacute and chronic angle-closure glaucoma*

\begin{tabular}{|c|c|c|}
\hline Result & No. of eyes & Notes \\
\hline $\begin{array}{l}\text { Cured } \\
\text { Controlled } \\
\text { Failed }\end{array}$ & $\left.\begin{array}{r}\text { I I } \\
3 \\
5\end{array}\right\} \begin{array}{l}78 \text { per } \\
\text { cent. }\end{array}$ & $\begin{array}{l}\text { Postoperative cataract I (2 yrs) } \\
\text { Angle } 75 \text { per cent. closure } \\
4 \text { Scheie-I successful }\end{array}$ \\
\hline Total & 19 & \\
\hline
\end{tabular}

medical treament). Filtration surgery was performed in the three eyes in which peripheral iridectomy had failed, in two of these successfully (Table V).

The chronic angle closures numbered $4 \mathrm{I}$; seven ( 17 per cent.) of these were blind when seen and were not treated. Of the remaining 34 eyes, nineteen were treated by peripheral iridectomy.

Control was achieved in fourteen. In seven eyes the angle before operation was estimated to be closed by more than 75 per cent. Of the five failures (all closed over more than 75 per cent. of the circumference of the angle), four eyes were subjected to filtration surgery with only one success. One patient refused further surgery.

Thus, of the nineteen eyes treated by peripheral iridectomy, the disease was controlled in fourteen ( 78 per cent.) (Table VI).

Thirteen eyes treated medically have all remained controlled during the 2-year period of this study.

Two eyes with subacute or chronic angle closure were successfully treated by Scheie operations.

\section{Summary}

Angle-closure glaucoma is said to be very rare in Negro communities from Central Africa. In the U.S.A. acute angle-closure is rare but chronic angle-closure glaucoma is seen.

The prevalence, symptomatology, clinical features, and case histories of angle-closure glaucoma are similar in South African Negroid and Caucasoid populations from the same glaucoma clinic, and similar to angle-closure glaucoma as seen in Caucasians elsewhere. There are some differences but, apart from the fact that acute angle-closure attacks are about half as frequent in Negroids as in Caucasoids, the differences are not fundamental and are probably related to differences in education and language.

South African Negroes therefore appear to differ from Negroes elsewhere. The reasons for this are not known, but some suggestions are made. They share a common gene pool with Negroes in Central Africa and the U.S.A. so that the reason is unlikely to be genetic. There may be a hidden cause in the different socio-economic background of Central Africa on the one hand and of South Africa and America on the other. Nevertheless there remains a striking difference in the prevalence of angle-closure glaucoma in South African and American Negroes and this is not understood, but is presumably related to environmental factors. 
Greater efforts are necessary to search for the disease in Negro populations to establish if there really is a difference between the South African Negro and Negroes living elsewhere.

The treatment of angle-closure in Negroes is discussed.

I wish to thank the iMedical Superintendents of the Johannesburg General Hospital, Baragwanath Hospital, and the St. John Eye Hospital, for access to case records. My thanks are also due to the registrars in the Departments of Ophthalmology who assist me in the Glaucoma Clinics.

Financial assistance was obtained from the University of the Witwatersrand Senate Research Grants Committee and the South African Medical Research Council.

\section{References}

AlPer, M. G., and LAUBACH, J. L. (Ig68) Arch. Ophthal. (Chicago), 79, 663 av-shalom, A. (1966) $\quad$ J. Israel med. Ass., 70, 250

Barkan, O. (1938) Amer. F. Ophthal., 21, I099

BARTHOlOMEW, R. s. (1971) Brit. J. Ophthal., 55, 693

BEIGHTON, P. H. (I97I) Personal communication

LOWE, R. F. (1972) Brit. J. Ophthal., 56, 13

LunTz, м. н. (1970) S. Afr. med. 7. 44, Suppl. (July ı), p.6

\section{(1971) Unpublished material.}

(1972) Amer. 7. Ophthal., 74, 581

Neumann, e., and zauberman, H. (1965) "Glaucoma Survey in Liberia". Amer. 7. Ophthal., 59, 8 RODGER, F. C. (1958) Ibid., 45, 343

SARKIES, J. W. R. (I953) Brit. F. Ophthal., 37, 6 I 5

SMITH, REDMOND J. H. (1965) “Clinical Glaucoma", p. 9. Cassell, London

sugar, H. s. (1957) The Glaucomas", 2nd ed., p. I02. Cassell, London

tobias, P. v. (1971) S. Afr. F. Sci., 67, 517 